УДК $327.56323 .22(477)$

ПОПКО С.М.

https://orcid.org/0000-0002-3050-2517

https://doi.org/10.33577/2313-5603.34.2020.52-63

\title{
СИСТЕМА КОНТРОЛЮ НАД ОЗБРОСННЯМ В УКРАЇНІ: ВЕРИФІКАЦІЯ ДОГОВОРНОЇ БАЗИ
}

Розкрито питання верифікаційної діяльності державних органів влади України щодо договорів у сфері контролю над озброєнням. На прикладі Управління верифікації Генерального штабу Збройних Сил України показано існуючі організаційно-правові засади для виконання комплексу заходів, пов'язаних 3 верифікацією архітектури європейської та національної безпеки в українських реаліях. Звернена увага на специфічний характер контролю над озброєнням та запропоновано підвищення ефективності їх функціонування в сучасних умовах державного управління національною безпекою. Зроблено висновки про те, що належна нормативно-правова основа у сфері безпеки та контролю над озброєннями, налагоджена в рамках вітчизняного законодавства система організаційних структур України, призначених для практичної реалізації заходів з контролю над озброєнням, як на території України, так і поза їі межами, а також встановлений порядок взаємодії державних органів центральної виконавчої влади складають основу верифікаційної діяльності в Україні та в цілому здатні забезпечити контроль над Міноборони України та 3С України положень міжнародних договорів та домовленостей у сфері контролю над озброєнням.

Ключові слова: ЗС України, система безпеки, геополітика, верифікація.

Від часу відновлення незалежності (1991р.), Україна неодноразово доводила світовій спільноті свою вірність демократичним принципам та нормам міжнародних договорів, а їі активна участь в роботі міжнародних організацій, зокрема у сфері контролю над озброєнням, вказують на значний внесок у зміцнення світової безпеки (Торкунов). 3 огляду на кризу системи міжнародної безпеки, яку, у тому числі, спровокувала російська агресія (2014 р.) в Україні, питання верифікаційної діяльності державних органів влади України щодо договорів у сфері контролю над озброєнням в Україні набуває особливого значення, оскільки в умовах дотримання взятих на себе зобов'язань в рамках міжнародних угод наша держава може вкотре підкреслити свою принциповість у дотриманні норм міжнародного права, а також заручитися підтримкою міжнародного співтовариства у протистоянні агресору.

Попко Сергій Миколайович, кандидат історичних наук, генерал-полковник, головний інспектор Міністерства оборони України, м. Київ.

(C) Попко C.M., 2020 
Аналіз вітчизняної історіографії засвідчує, що проблема верифікаційної діяльності є недостатньо висвітленою. Нечисленні праці цієї тематичної ніші хоча й розкривають певні аспекти адаптації України до систем колективної безпеки євроатлантичного простору, проте не відображають механізму здійснення верифікаційної діяльності «на місцях». Саме тому, метою статті є дослідження верифікаційної діяльності державних органів влади щодо договорів у сфері контролю над озброєнням в Україні.

Верифікація - специфічний вид міжнародного співробітництва, спрямований на використання міждержавних систем та механізмів міжнародної безпеки шляхом дотримання договірних зобов'язань у сфері роззброєння та контролю над озброєнням, моніторингу виконання зобов'язань зарубіжними державами-учасницями міжнародних договорів (Положення про організацію та проведення міжнародного співробітництва..., 2006). Основу верифікаційної діяльності становить нормативно-правова база у сфері безпеки та контролю над озброєннями, «вертикаль» організаційних структур України, призначених для практичної реалізації заходів з контролю над озброєнням, як на території України, так і поза іiі межами, а також встановлений порядок взаємодії державних органів центральної виконавчої влади під час зазначених заходів. Визначальною передумовою ефективного функціонування державно-управлінської системи у сфері контролю над озброєнням є організаційна структура державного управління, зорієнтована на забезпечення належної реалізації цілей і завдань. Цілі та функції як держави, так і державного управління випливають з її Конституції (Мельник, 2009: 44).

Юридичне підгрунтя контролю над озброєнням державою забезпечують основоположні нормативно-правові документи стратегічного планування для гарантування національної безпеки: Конституція України, укази Президента України з питань забезпечення національної безпеки та оборони, Стратегії національної безпеки та Воєнної доктрини України, Стратегії воєнної безпеки, Стратегічного оборонного бюлетеня, Державні програми розвитку озброєння та військової техніки, Державні програми реформування та розвитку оборонно-промислового комплексу та ін. Головними суб'єктами стратегічного планування у сфері національної безпеки в межах наданих повноважень є Верховна Рада України, Президент України, Кабінет Міністрів України, Рада національної безпеки і оборони України, Генеральний штаб Збройних Сил України, 
місцеві державні адміністрації та органи місцевого самоврядування; урядові комісії, міжгалузеві та відомчі робочі групи тощо (Мельник, 2009: 46).

Координувальним органом з питань верифікаційної діяльності у ЗС України є Управління верифікації Генерального штабу ЗС України, яке забезпечує інспекційну діяльність на території України та поза ії межами, збирає, опрацьовує інформацію та повідомлення згідно 3 міжнародними договорами у галузі роззброєння та контролю над озброєннями незалежно від підлеглості об'єктів інспектування та має можливість залучати представників правоохоронних органів для забезпечення виконання міжнародних договорів та угод під час проведення інспекційної діяльності на території України (Положення про Генеральний штаб Збройних Сил України, 2019).

Основні завдання ЗС України як головної державної структури у сфері верифікаційної діяльності: дотримання встановлених обмежень для певних видів озброєнь та військової техніки у кількісному та якісному відношенні; підготовка та передача поточної та щорічної обмінної інформації, передбаченої міжнародними договорами та угодами; підготовка місць інспекцій на території України; забезпечення супроводжень іноземних інспекційних груп на території України; моніторинг виконання державамиучасницями зобов'язань, передбачених міжнародними договорами та угодами, шляхом проведення контрольних заходів; участь у переговорному процесі, робочих зустрічах та семінарах 3 питань міжнародної безпеки та контролю над озброєннями; розробка нормативно-правової бази щодо практичної реалізації міжнародних договорів та угод на території України (Договір про звичайні збройні сили в Свропі, 1992).

Щороку розробляється план верифікаційної діяльності України за міжнародними договорами та угодами у галузі контролю над озброєннями (на підставі та 3 урахуванням основоположних нормативно-правових документів стратегічного планування для забезпечення національної безпеки та безпосередньо Положення про організацію та проведення міжнародного співробітництва у Міністерстві оборони та ЗС України, затвердженого наказом Міністра оборони України від 24.08.06 № 502 (Положення про організацію та проведення міжнародного співробітництва..., 2006), міжнародних зобов'язань України згідно з Договором про звичайні 
збройні сили в Європі (Договір про звичайні збройні сили в Європі, 1992), Віденським документом 2011 року переговорів щодо заходів зміцнення довіри та безпеки (Венский документ 2011 года..., 2011), Договором про відкрите небо (Державна иілььова програма реалізаиії Договору з відкритого неба, 2012), Договором про скорочення та обмеження стратегічних наступальних озброєнь (Договір між Союзом Радянських Соціалістичних Республік $i$ Сполученими Штатами Америки..., 1991), угодами між Кабінетом Міністрів України та урядами інших держави щодо заходів у сфері розвитку двосторонніх військових зв'язків). Міжвідомчим державним органом погодження і координації політики України в галузі роззброєння та контролю над озброєнням за Указом Президента України (Про оборону України, 1992) був створений Національний комітет України з питань роззброєння (НКР).

За рекомендацією Генеральної військової інспекції при Президентові України у 2000 році створено Центр військового співробітництва і верифікації ГШ ЗС України. Зазначимо, що організаційні зміни 2002-2003 років проходили на тлі підвищеної уваги міжнародного співтовариства щодо дотримання Україною міжнародних зобов'язань у сфері контролю над озброєннями, зокрема після звинувачень України у продажу озброєння терористичним організаціям (Повідомлення деяких ЗМІ щодо причетності України до продажу афганським талібам танків Т-55) чи диктаторським режимам (Про забезпечення роботи міжнародних експертів..., 2005) тощо.

Все ж визначальна роль у процесі верифікаційної діяльності належить Управлінню верифікації, яке реалізовує військово-політичні аспекти зовнішньополітичного курсу держави у сфері контролю над озброєнням. Також управління займається забезпеченням виконання міжнародних договорів у сфері контролю над озброєннями інспекційної діяльності на території України та поза іï межами, збирання, опрацювання інформації та повідомлень відповідно до цих міжнародних договорів незалежно від підлеглості об'єктів інспектування. Управління верифікації також покликане здійснювати керівництво та координацію діяльності підпорядкованими регіональними центрами (групами) забезпечення реалізації договорів про скорочення озброєнь, контроль за їх діяльністю.

3 метою виконання поставлениих завдань щороку розробляється низка планувальних документів: План верифікаційної діяльності 
України за міжнародними договорами та угодами у сфері контролю над озброєнням, погоджений Прем'єр-міністром України (План зовнішньої верифікаційної діяльності України..., 2013), Плани перевірки оголошених місць Збройних Сил, а також інші планувальні документи в межах своєї компетенції.

Управління верифікації проводить експертну оцінку та розробку проектів законів України, розпоряджень Кабінету Міністрів України, інших нормативно-правових актів, наказів і директив Міністра оборони України, начальника ГШ ЗСУ України 3 питань, що належать до компетенції Управління верифікації, прогнозування перспектив та тенденцій розвитку, ефективності системи контролю над озброєнням; відпрацювання пропозицій щодо формування та реалізації державної політики у сфері контролю над озброєнням до проектів щорічних Указів Президента України щодо складу та вказівок делегаціям України на Віденських, Женевських та Вашингтонських переговорах у рамках Спеціальної контрольної комісії за Договором між СРСР і США про ліквідацію ракет середньої та меншої дальності, Спільної консультативної групи за Договором про звичайні збройні сили в Європі, Консультативної комісії з відкритого неба за Договором з відкритого неба, Форуму Організації з безпеки та співробітництва в Свропі із співробітництва в галузі безпеки (Про делегацію України для участі в переговорах..., 2008).

Управління верифікації також бере участь у переговорах, конференціях, робочих зустрічах та інших заходах 3 питань, що належать до його компетенції; у зборі та узагальненні пропозицій міжнародних організацій 3 питань контролю над озброєннями, доведення їх до відповідних органів державного управління для подальшого опрацювання. Підготовка обмінної інформації за Україну, передбачену міжнародними договорами, та іiі передачу державам-учасницям відбувається офіційними каналами передачі інформації через міжурядову лінію зв'язку (Матвієнко, 2014: 35-40).

Персонал Управління верифікації залучається до участі у плануванні використання літаків спостереження України, розробці двосторонніх та багатосторонніх міжнародних угод з їх застосування; участі у переговорах у складі державних делегацій України; взаємодії з верифікаційними структурами інших держав-учасниць 3 проведення взаєморозрахунків. Управління розробляє пропозиції до щорічного проекту Закону України «Про Державний 
бюджет України» за напрямом «Верифікаційна діяльність», формує та супроводжує бюджетний запит до моменту подання за Міністерство оборони України; надає засобам масової інформації (відповідно до визначеного порядку) об' єктивну інформацію щодо проведення Збройними Силами заходів верифікаційної діяльності для сприяння у формуванні позитивної громадської думки та зміцнення довіри суспільства (Матвієнко, 2014: 35-40).

Управління верифікації для виконання покладених на нього завдань має право в установленому порядку з питань, що належать до його компетенції: залучати установи та організації, які належать до сфери управління Міністерства оборони України та Генерального штабу, до діяльності, пов'язаної з практичною реалізацією міжнародних зобов'язань держави у сфері контролю над озброєнням; здійснювати свої повноваження безпосередньо та через підпорядковані верифікаційні підрозділи Збройних Сил; здійснювати погодження проектів нормативно-правових актів 3 питань верифікаційної діяльності; надавати пропозиції щодо визначення засад державної політики та реалізовувати військовополітичні аспекти зовнішньополітичного курсу держави у сфері контролю над озброєннями; за дорученням начальника Генерального штабу та його заступника скликати наради, створювати робочі групи, з включенням фахівців до їх складу, за погодженням 3 відповідними керівниками структурних підрозділів Міністерства оборони України, Генерального штабу та командувань видів Збройних Сил України для вирішення питань, пов'язаних 3 реалізацією міжнародних зобов'язань держави у сфері контролю над озброєннями; представляти інтереси України, Міністерства оборони України та Генерального штабу в міжнародних організаціях та державних органах; у межах компетенції проводити експертну оцінку матеріальних носіїв інформації, які плануються для передачі іншим державам та міжнародним організаціям. Значна кількість структур, 3 якими здійснюється погодження, особливо на верхніх ланках міністерської влади, суттєво ускладнює процес прийняття рішень та їх безпосереднє виконання, оскільки збільшується зайва бюрократизація. Введення Національного центру з державного контролю над озброєнням дозволить мінімізувати часові показники, знизити трудовитрати, оптимізувати вирішення завдань у сфері державного контролю над озброєнням. 
Обгрунтування організаційно-правових засад у цьому контексті має здійснюватися крізь форму введення концепції державного контролю над озброєнням, закону України про державний контроль над озброєнням та створення комплексної структури у вигляді окремої державної одиниці зі статусом національної (Матвієнко, 2014: 35-40).

3 Управлінням верифікації співпрацюють представництва України при міжнародних організаціях та Департамент міжнародної безпеки Міністерства закордонних справ України, яким оперативно надається кваліфікована інформація для вироблення позиції України за напрямами військово-політичних договірних зобов'язань. В рамках зазначеного дослідження пропозиції щодо трансформації організаційно-правових засад контролю над озброєнням на міжнародному рівні не розглядаються. Водночас висновки роботи можуть бути застосовані при виробленні механізмів деескалації гібридного протистояння з урахуванням імплементації Віденського документа як найбільш актуального на сьогодні. На основі останнього розробляються двосторонні угоди України, що є реальним внеском для попередження агресії. Порядок взаємодії 3 причетними структурними підрозділами Міністерства оборони України, Генерального штабу Збройних Сил України визначено в інструкціях, затверджених (введених в дію) відповідними наказами Міністра оборони України, більшість 3 яких, щоправда, потребує оновлення. Для вирішення проблемних питань реалізації договорів та угод у сфері контролю над озброєнням на постійній основі працюють: Форум з безпеки і співробітництва в Європі (Відень, Австрія); Спільна консультативна група за Договором про звичайні збройні сили в Свропі (Відень, Австрія); Консультативна Комісія з відкритого неба (Відень, Австрія); Спільна Комісія по виконанню та інспекціях за Договором про СНО (Женева, Швейцарія); Верифікаційний координаційний комітет НАТО (Брюссель, Бельгія). Представники Управління у складі делегації України згідно з відповідними Указами Президента України (Про делегацію України для участі в переговорах у рамках Форуму ОБСС із співробітництва в галузі безпеки, Спільної консультативної групи та Консультативної комісії з відкритого неба) та за рішенням керівництва Генерального штабу Збройних Сил України беруть участь у засіданнях згаданих робочих органів ОБСС та інших міжнародних організацій. 
Відповідно до низки постанов КМУ створені регіональні верифікаційні структури: Центри забезпечення реалізації договорів про скорочення озброєнь у Львові та Одесі, група забезпечення реалізації договорів про скорочення озброєнь у Житомирі, регіональні представники у Дніпрі, Харкові, Миколаєві, Вінниці, Чернігові тощо. Основними завданнями зазначених регіональних верифікаційних структур є: прийом та відправка іноземних інспекційних груп у визначених пунктах в’їзд/виїзду міст Київ, Львів, Одеса, Харків, Дніпро, тимчасово окупований Сімферополь; організація та проведення супроводжень іноземних інспекційних груп у зонах відповідальності; збір, опрацювання та надання до Управління верифікації даних про наявність і переміщення військової техніки та озброєння, а також іншої інформації, передбаченої міжнародними договорами у сфері контролю над озброєннями; надання інформаційної та методичної допомоги командирам об'єднань, з'єднань і військових частин щодо підготовки підпорядкованих їм оголошених місць та об'єктів контролю до проведення інспекцій; контроль готовності оголошених місць та об'єктів контролю до проведення інспекцій; взаємодія 3 регіональними структурами Державної митної служби, Державної прикордонної служби, Міністерства внутрішніх справ України. При цьому двосторонні угоди з суміжними країнами передбачають використання певної прикордонної смуги при проведенні інспекційних заходів на різних відстанях, в залежності від держави, з якою цю угоду укладено (Управління верифікації Генерального штабу Збройних Сил України).

Нові виклики та загрози національній безпеці держави, впровадження нездійснюваних раніше форм імплементації міжнародних договорів та угод, що вперше застосовуються на території України 3 початком військової агресії, концентрують увагу на трансформації організаційно-правових засад державного контролю над озброєнням. Зокрема, імплементація Мінських домовленостей, пов'язаних 3 врегулюванням бойових дій на Сході України, які вважаються «дорожньою картою» та безпековим компонентом й одним із ключових складників втілення в умовах належного рівня безпеки політичного процесу (Управління верифікації Генерального штабу Збройних Сил України), потребують окремого підходу і зусиль в організації верифікаційної діяльності та мають перспективи трансформації організаційно-правових засад як на відомчому рівні Міністерства оборони України, так і для організації міжвідомчої 
взаємодії. Заходи з технічного захисту інформації здійснюються відповідно до Указу Президента України від 06.10.2000 зі змінами «Про Положення про технічний захист інформації в Україні» (Про Положення про технічний захист інформації в Україні, 1999).

Таким чином, в Україні впроваджені та існують повноцінні організаційно-правові засади у сфері контролю над озброєнням для підвищення ефективності їх функціонування в сучасних умовах державного управління національною безпекою. Виконання комплексу заходів, пов'язаних 3 верифікацією архітектури європейської та національної безпеки в українських реаліях, покладені на Управління верифікації Генерального штабу Збройних Сил України. Контроль над озброєнням є специфічним видом міжнародного співробітництва, який належить до воєнно-політичної сфери, що реалізується в рамках механізмів міжнародної безпеки шляхом дотримання міжнародних договірних зобов'язань у сфері роззброєння та контролю над озброєнням, моніторингу виконання зобов'язань зарубіжними державами-учасницями міжнародних договорів. Міністерство оборони України, Збройні Сили України $\epsilon$ практичною складовою державних верифікаційних структур України. Мета контролю над дотриманням Міноборони України та ЗСУ положень міжнародних договорів та домовленостей у сфері контролю над озброєнням полягає у повному та якісному виконанні покладених на них завдань щодо практичної реалізації міжнародних зобов'язань держави у сфері міжнародної безпеки та контролю над озброєннями. Належна нормативно-правова основа у сфері безпеки та контролю над озброєннями, налагоджена в рамках вітчизняного законодавства система організаційних структур України, призначених для практичної реалізації заходів 3 контролю над озброєнням, як на території України, так і поза іiі межами, а також встановлений порядок взаємодії державних органів центральної виконавчої влади в ході зазначених заходів складають основу верифікаційної діяльності в Україні.

\section{Використані посилання}

Венский документ 2011 года о мерах укрепления доверия и безопасности. (2011). Доступно: http://www.mid.ru/ bdomp/ns-dvbr.nsf/ [Дата звернення 7 серпня 2020].

Державна цільова програма реалізації Договору з відкритого неба. (2012). Офічійний вісник Украӥни. 28.09.2012. № 71. С. 22.

Договір про звичайні збройні сили в Європі. (1992). Доступно http:// https://zakon.rada.gov.ua/laws/show/994_314\#Text [Дата звернення 7 серпня 2020] 
Договір між Союзом Радянських Сочіалістичних Республік і Сполученими Штатами Америки про скорочення й обмеження стратегічних наступальних озброєнь 1991 року. (1991). Доступно: https://zakon.rada.gov.ua/laws/ show/840_050\#Text [Дата звернення 7 серпня 2020]

Матвєєнко О. (2014). Організаційно-правові засади передачі обмінної інформації за договорами у сфері контролю над озброєнням. Актуальні проблеми управління інформачійною безпекою держави: зб. матеріалів наук.практ. конф., 20 березня 2014 року. Київ, Ч. 2. 260 с.

Мельник А. (2009). Державне управління. Київ: Знання. 584 с.

Нижник Н., Машков О. (1998). Системний підхід в реалізації державного управління. Київ: Вид-во УАДУ. 159 с.

План зовнішньої верифікаџійної діяльності України за міжнародними договорами та угодами у галузі контролю над озброєнням у 2013 рочі. (2013). Доступно: https://ips.ligazakon.net/document/MUS30113 [Дата звернення 7 серпня 2020].

Повідомлення деяких ЗМI щуодо причетності України до продажу афганським талібам танків T-55. (2002). Доступно: http://old.mil.gov.ua/news/ print_news.php?lang=ua\&id=593 [Дата звернення 1 серпня 2020].

Положення про організаџію та проведення міжнародного співробітництва у Міністерстві оборони Украӥни та Збройних Силах Украӥни: Наказ Міністра оборони України. (2017). Доступно: https://ips.ligazakon.net/document/MUS30113 [Дата звернення 1 серпня 2020].

Про делегачію Украӥни для участі в переговорах у рамках Форуму ОБСС із співробітництва в галузі безпеки, Спільної консультативної групи та Консультативної комісії з відкритого неба: Указ Президента Украӥни. (2008). Доступно: https://ips.ligazakon.net/document/U007_17 [Дата звернення 1 серпня 2020].

Про забезпечення роботи міжнародних експертів з питань експорту станцій радіоелектронної розвідки «Кольчуга»: Розпорядження Президента Украӥни. (2005). Доступно: https://zakon.rada.gov.ua/laws/show/352/2002$\% \mathrm{D} 1 \% 80 \% \mathrm{D} 0 \%$ BF\#Text [Дата звернення 1 серпня 2020].

Про оборону України: Закон України. (1992). Відомості Верховної Ради України. 1992, № 9. 106 с.

Про оголошення міст Києва, Львова, Одеси, Сімферополя, Дніпропетровська та Харкова пунктами в'їду (виїзду) для здійснення інспекиійної діяльності за міжнародними угодами: Постанова Кабінету Міністрів України від 25 жовтня 1992 р. (1992). Доступно: https://zakon.rada.gov.ua/laws/show/59692-\%D0\%BF\#Text [Дата звернення 1 серпня 2020].

Положення про Генеральний штаб Збройних Сил України: Указ Президента Украӥни. (2019). Доступно: https://zakon.rada.gov.ua/laws/show/23/2019\#Text / [Дата звернення 1 серпня 2020].

Про Положення про технічний захист інформаџії в Україні: Указ Президента України. (1999). Доступно: http://zakon.rada.gov.ua/laws/ show/1229/ 99\#Tехt [Дата звернення 1 серпня 2020].

Торкунов А. Стратегічний паритет $i$ контроль над озброєннями. Доступно: http://crk-knteu.kiev.ua/52970-Strategicheskiiy_paritet_i_kontrol_ nad_ vooruzheniyami.html [Дата звернення 1 серпня 2020].

Управління верифікації Генерального цтабу Збройних Сил Украӥни. Доступно: http://archive.ec/oGAf/image [Дата звернення 1 серпня 2020]. 


\section{References}

Vienna Document of 2011 on Confidence- and Security-Building Measures (2011) URL: http://www.mid.ru/ bdomp / ns-dvbr.nsf / (ukr).

State target program for the implementation of the Open Skies Agreement. Official Gazette of Ukraine. 28.09.2012 № 71, p. 22. (ukr).

Treaty on Conventional Armed Forces in Europe URL: http://zakon2.rada .gov.ua/laws/show/994_314(ukr).

Treaty on the Reduction and Limitation of Strategic Offensive Arms of the USSR USA URL: https://zakon.rada.gov.ua/laws/show/840_050\#Text (ukr).

Matveenko O. (2014) Organizational and legal bases of transfer of exchange information under agreements in the field of arms control. Actual problems of information security management of the state: coll. materials scientific-practical. conf., March 20, 2014. Part 2., pp. 43-45. (ukr).

Melnyk A. (2009) Public administration. Kyiv, 584 p. (ukr).

Nyzhnyk H., Mashkov O. (1998) System approach in the implementation of public administration. Kyiv: UADU Publishing House, 159 p. (ukr).

Plan of external verification activities of Ukraine under international treaties and agreements in the field of arms control in 2013 URL: https://ips.ligazakon. net/ document/MUS30113 (ukr).

Some media reports on Ukraine's involvement in the sale of T-55 tanks to Afghan Taliban URL:http://old.mil.gov.ua/news/print_news.php?lang=ua\&id=593 (ukr).

Regulations on the organization and conduct of international cooperation in the Ministry of Defense of Ukraine and the Armed Forces of Ukraine: Order of the Minister of Defense of Ukraine URL: https://ips.ligazakon.net/document/MUS30113 (ukr).

On the delegation of Ukraine to participate in the negotiations within the OSCE Forum for Security Co-operation, the Joint Consultative Group and the Open Skies Consultative Commission: Decree of the President of Ukraine URL: https:// ips. ligazakon.net/ document/ (ukr).

On ensuring the work of international experts on the export of electronic reconnaissance stations "Kolchuga": Order of the President of Ukraine URL: http://zakon2.rada.gov.ua/laws/show/352/2002-\%D1\%80\%D0\%B (ukr).

About the defense of Ukraine: Law of Ukraine URL: http://zakon2.rada. gov.ua/ laws/show/1932-12/ (ukr).

About the announcement of the cities of Kyiv, Lviv, Odessa, Simferopol, Dnipropetrovsk and Kharkiv as points of entry (exit) for carrying out inspection activities under international agreements. Resolution of the Cabinet of Ministers of Ukraine. October 25, 1992 URL: https://ips.ligazakon.net/document/ (ukr).

On the Regulation on the Ministry of Defense of Ukraine and the Regulation on the General Staff of the Armed Forces of Ukraine: Decree of the President of Ukraine URL: http://zakon2.rada.gov.ua/laws/show/406/2011/ (ukr).

About Regulations on technical protection of information in Ukraine: Decree of the President of Ukraine URL: http://zakon3.rada.gov.ua/laws/show/ 1229/99/ print1481587544298883 (ukr).

Torkunov A. Strategic parity and arms control URL: http://crk-knteu.kiev.ua/ 52970-Strategicheskiiy_paritet_i_kontrol_nad_vooruzheniyami.html (ukr).

Department of Verification of the General Staff of the Armed Forces of Ukraine URL: http://archive.ec/oGAf/image (ukr). 


\section{Popko S. \\ ARMS CONTROL SYSTEM IN UKRAINE: VERIFICATION OF THE CONTRACTUAL BASE}

This scientific article reveals the issue of verification activities of state authorities of Ukraine on agreements in the field of arms control in Ukraine. The example of the Verification Department of the General Staff of the Armed Forces of Ukraine shows the existing organizational and legal framework for the implementation of a set of measures related to the verification of the architecture of European and national security in the Ukrainian reality. It is noted that the main tasks of the Armed Forces of Ukraine, as the main state structure in the field of verification activities - is compliance with certain restrictions for certain types of weapons and military equipment in quantitative and qualitative terms, preparation and transmission of current and annual exchange information provided by international treaties and agreements. places of inspections on the territory of Ukraine, providing support for foreign inspection teams on the territory of Ukraine, as well as monitoring the implementation by member states of obligations under international treaties and agreements, by conducting control measures, etc.

It is stated that in line with the studied problems, an important role is assigned to regional verification structures - Centers for ensuring the implementation of arms reduction agreements, which receive and send foreign inspection teams at certain points of entry / exit, accompany foreign inspection teams in areas of responsibility, collect, process and provide the Verification Office with data on the availability and movement of military equipment and armaments, as well as other information provided by international agreements in the field of arms control, etc. Attention is paid to the specific nature of arms control and it is proposed to increase the efficiency of their functioning in the current conditions of state management of national security. It is concluded that the appropriate regulatory framework in the field of security and arms control, established within domestic legislation, the system of organizational structures of Ukraine, designed for the practical implementation of measures to control arms, both in Ukraine and abroad, as well as the established procedure for interaction of state bodies of central executive power, form the basis of verification activities in Ukraine and in general are able to ensure control over the Ministry of Defense of Ukraine and the Armed Forces of Ukraine provisions of international treaties and agreements in the field of arms control.

Keywords: Armed Forces of Ukraine, security system, geopolitics. 